\title{
Race and Socioeconomic Status Differences in Study Abroad Participation: The Role of Habitus, Social Networks, and Cultural Capital
}

\author{
Jennifer Simon and James W. Ainsworth \\ Department of Sociology, Georgia State University, University Plaza, General Classrooms 1063, Atlanta, GA 30303, USA \\ Correspondence should be addressed to James W. Ainsworth, ainsworth@gsu.edu
}

Received 19 July 2012; Accepted 22 August 2012

Academic Editors: R. Martens and G. Sideridis

Copyright ( $\odot 2012$ J. Simon and J. W. Ainsworth. This is an open access article distributed under the Creative Commons Attribution License, which permits unrestricted use, distribution, and reproduction in any medium, provided the original work is properly cited.

\begin{abstract}
This study examines how race and socioeconomic status contribute to disparities in study abroad participation. Our mixed methods approach provides a broad overview of the selection process into study abroad using national data. It also provides a nuanced understanding of the mechanisms that perpetuate inequality among Black and lower class students. Both quantitative and qualitative results show that students' habitus, social networks, and cultural capital shape their study abroad experiences. We find that students with a positive predisposition toward internationalization (having foreign-born parents and/or experiencing different cultures overseas) were more likely to study abroad. Whites and high socioeconomic status students were also more likely to have family and friends who valued study abroad than were lower socioeconomic status and Black students. These advantaged students were better able to acquire and use cultural capital when accessing information from institutional agents. They were also more likely to possess the knowledge and background that complied with institutional standards. These factors contributed significantly to the race and class disparities in study abroad participation. This study contributes to the scant literature on study abroad by revealing mechanisms through which the reproduction of inequality is shaped in the university setting. We argue that patterns found to apply to this process are likely to take place in other processes in higher education as well.
\end{abstract}

"What we do know in a global world today is that travel is important. Every major university in this country is trying to raise money in order to get their undergraduates to live and have an experience overseas. They think that it is critical to come into the new world. David Rockefeller just gave Harvard a hundred million dollars to ensure that every undergraduate has a chance to go. ${ }^{i}$ This is not just an elitist thing. David Boren, who is the president of the University of Oklahoma, is trying to get every student at the University of Oklahoma to go overseas. We know that this is now a prerequisite to being, to living, in a very complex world and having positions of responsibility." —David Bergen, Director of the Harvard Center for Public Leadership on CNN Newsroom September 3, 2008.

\section{Introduction}

Despite the efforts of U.S. educational institutions to encourage study abroad ${ }^{1}$ participation, Black ${ }^{2}$ and lower socioeconomic status students are severely underrepresented. As a consequence of this exclusion, many lack the valuable resources study abroad programs offer; resources that are increasingly important in our globalizing world. The past literature reveals that a combination of individual and institutional factors influences study abroad involvement [16]. However, these studies fail to theoretically address how minorities and the poor are left out. Our study uses indepth qualitative evidence to examine the processes and mechanisms that contribute to racial and class disparities in 
study abroad involvement. We compliment this examination with a nationally representative quantitative analysis that tests whether these patterns are generalizable.

Study abroad programs provide cultural immersion and unique experiences in new and unfamiliar environments. Cultural advantages include a reduced propensity for ethnocentric and prejudicial behaviors [4], improved cultural awareness, an expanded worldview [7-11], adoption of a more critical view of events in their home countries [12], and more maturity [7]. The unique viewpoints gained through study abroad can also potentially impact foreign policy goals and sensitivity to other countries' needs among present and future policy makers $[13,14]$. This type of global experience is also advantageous in the domestic and international job market, especially in foreign policy and other internationally related occupations. In fact, study abroad is considered to be a prerequisite for careers in the international arena including work in organizations such as the United Nations, the World Bank, and the Foreign Service $[15,16]$. If poor and/or minority students continue to participate in study abroad programs at lower rates, they will be excluded from these cultural and labor market advantages.

\section{Who Participates in Study Abroad?}

Stark disparities in participation of Black and low socioeconomic students is related to the historical development of study abroad programs. Before the 1980s, study abroad programs were considered luxuries and were available primarily to children of the wealthy. This was due in part to the high cost of participating in these programs [17]. Other factors included an elitist perception of study abroad, the duration of programs, often a semester or more, and the fact that study abroad was only offered at the most exclusive schools, which overwhelmingly consisted of wealthy White students $[17,18]$. By the late 1980s and the early 90s, enrollment in study abroad programs grew rapidly in response to globalization and the increased international orientation of college curricula [19]. During this time, enrollment in study abroad increased primarily among middle-class students and began to include small numbers of lower socioeconomic statuses and minority students.

Despite recent improvement in diversity, enrollment in study abroad continues to be largely restricted to White, affluent, middle-, or upper-middle class female students, who study the humanities or social sciences [1]. A significant proportion of the U.S. college population, including Blacks and lower socioeconomic status students, don't typically participate in study abroad programs [2, 16, 19-21]. For example, in 2004/5 among students at four-year institutions, while White students comprised $66 \%$ of the population, their representation in study abroad programs was $83 \%$ compared to a meager $3.5 \%$ Black student representation from a college population of $12.5 \%$ [22]. Past studies suggest that these racial disparities result from a combination of institutional factors, which include lack of support from faculty and staff to study abroad [19, 23], lack of access to information and peer networks [5], limited program options
$[3,19]$, individual constraints such as lack of finances to fund study abroad [3-5, 23], limited family support [23], and the perception of study abroad as something that is beyond the reach of Black students [24].

Surprisingly, little research has focused on the direct impact of social class on students' participation in study abroad. Some research cites social class as a major reason for disparate participation [1, 25-27]. They reveal that the advantages and resources associated with being middle or upper class make it easier for these students to take part. Lambert [18] argues that members of lower socioeconomic classes are underrepresented in study abroad primarily because of inadequate finances. Similarly, Booker [1] noted that participants in study abroad are less likely to be reliant on financial aid and/or employment to attend college (page 34). Finally, the children of middle- and upper-class Whites are more likely to have been exposed to international travel opportunities and to interact, or know, friends who have gone abroad [23]. Although these studies identify barriers to study abroad participation, they don't offer theoretical explanations of how these barriers manifest themselves. Our contribution to the literature is to present a more nuanced understanding of disparities in study abroad participation and the processes that contribute to them.

\section{Causes of Racial and Class Disparities in Study Abroad Participation}

Beyond the obvious role financial inequality plays in creating disparities in study abroad participation, sociological theory suggests several other mechanisms that likely exacerbate such disparities. These mechanisms include differences in student habitus; the fact that students are embedded in distinct social networks; the differential possession, activation, and rewarding of students' cultural capital; institutional factors which may shape opportunities to study abroad. These mechanisms are discussed in turn.

3.1. Financial Mechanisms. Many see economic factors as the main hindrance to study abroad participation, especially for Black students $[2,4,5,23,28]$. Black and lower socioeconomic status students are often dependent on financial aid and cannot afford the additional expense of an overseas educational experience $[19,23]$. According to Hembroff and Rusz [4], many minority students work during the summer, when many study abroad programs occur. These situations present a difficult decision for students who would have to forego earnings and/or to incur new costs to study abroad. Alternatively, Chichester and Akomolafe [16] argue that financial constraints, although a serious barrier, are not the main impediment for Blacks. They contend that a majority of U.S. campuses have separate funding (scholarships and grants) available, but institutions don't adequately promote these financial options to minority students. "Many studyaboard professionals say colleges must also confront the psychological factors that discourage minority students from studying abroad. "It's not just that there is not the interest or the money," says Peggy Blumenthal, executive vice president 
at the Institution of International education... "they aren't even hearing it's a possibility." [29]." So, while economic inequality is likely a cause of disparities in study abroad, factors other than finances may also limit the involvement of poor and minority students.

3.2. Habitus. Social class may be viewed not only as the economic position people occupy in a society but as "attitudes, beliefs, experiences, and perceptions of one's social world" or what Bourdieu [30] terms "habitus." Swartz describes habitus as "a set of deeply internalized master dispositions that generate action" [31]. One's habitus is influenced by social class background and race, and such orientations and dispositions can shape expectations of, and participation in, study abroad. Clearly, students choose to study abroad, but the choices individuals make are shaped and constrained by their social location and habitus.

High socioeconomic status parents possess the habitus that is most likely to encourage study abroad. These families are more likely to expose their children to international travel, foreign cultures, and materials about international experiences. It follows these children would internalize the belief that study abroad is a "natural" thing to do, and that it fits well with their educational goals. Consequently, they are more likely to take courses, such as foreign languages, to satisfy study abroad requirements and pursue other opportunities that encourage study abroad. Advantaged students may also view study abroad as an escapist opportunity to "find themselves." As Nieoczym [32] suggests, the concept of "finding yourself" is a middle-class construct, and study abroad appeals to this need to escape their present situation.

Less advantaged students may misconstrue study abroad as an unnecessary luxury. Those who don't live or attend school in areas that foster an international outlook are less likely to be exposed to people who have studied abroad. They may develop a limited frame of reference, whereby study abroad is not a part of their habitus and not seen as suitable for people like them. While this theoretical argument is logically applied to low socioeconomic status students, it may be less applicable to racial minorities such as Blacks. Research has challenged the stereotypical notion that Black students are not interested in study abroad $[2,19,33]$. Carroll [2] finds that Black students are highly interested in broadening their educational experience overseas. However, they were also the group most likely to report perceived barriers to study abroad. Such barriers can include the biased orientations and dispositions of gatekeepers in the study abroad process. According to Carter [3], school personnel affiliated with the study abroad process may neglect minority students because of their perception that Blacks are not interested in study abroad. This perception is not only a function of individual prejudice but a boarder manifestation of institutionalized racism. As studies have shown, this systemic racism is deeply embedded in the institutional policies and everyday actions of these institutions, which ultimately influences disparate educational outcomes $[34,35]$. A prime example of hidden racism is the promotion of study abroad programs to specific populations and not others. Unfortunately, this racism is supported by the school personnel's prejudicial assumptions that all Blacks are poor, that they lack the necessary educational requirements, or that study abroad is not relevant to their lives. If study abroad personnel hold such views, it could limit the development of programs that encourage Black participation.

3.3. Social Networks. Social networks is another concept that helps explain class and racial disparity in study abroad participation. It can be defined as "social relationships from which an individual is potentially able to derive institutional support, particularly support that includes the delivery of knowledge-based resources" [36]. Lareau [37] reported that upper-middle class parents are more likely to have relatives and friends who are educators and, therefore, have inside information about schools. They are also more likely to have relatives or acquaintances with experience of living and studying overseas. These relationships help them secure advantage for their children due to "inside knowledge and information" about the study abroad process. Miller [27] notes that study abroad participants report that their decisions to study abroad were influenced by information from their social networks on how to navigate the process. These social circles include family members, friends, and high school teachers. Many of these "networks began even before the student went to university" (page 123). These class-based network resources must be "activated" in order to gain a social advantage [37-39]. Activation of resources requires conscious negotiation and strategizing. The knowledge of how to adequately draw upon these resources to obtain advantages is usually skewed towards those with higher socioeconomic status.

While children of middle- or upper-class families have a variety of networks available to them, low income individuals and racial minorities are usually excluded from crucial social networks that provide the most up-to-date and accurate information about educational opportunities. This exclusion can have an impact on the decision of whether to participate in study abroad. According to Van Der Meid [6], the resource that best promotes study abroad are returning students who relay their international experiences and encourage others to participate. Poor and/or Black students often lack this important network and may be deprived of the guidance and inspiration from their peers.

3.4. Cultural Capital. Related to habitus, and shaped by social networks, is the cultural capital of students and their families. For Bourdieu, cultural capital is regarded as the general cultural background, knowledge, experiences, disposition, and skills that are transmitted from one generation to the next $[30,40]$. Cultural capital functions as power in particular institutional settings and are invested in these same settings to attain specific advantages. Similarly, Lamont and Lareau [41] define cultural capital as "widely shared, high status cultural signals (attitudes, formal knowledge, behaviors, goods, and credentials) used for social and cultural exclusion (page 156)." Students with cultural capital that is rewarded by gatekeepers are more likely to successfully negotiate educational processes such as study abroad. 
Lareau [37] posits a three-stage process for transforming resources into cultural capital and then into social benefits. First, cultural resources need to be possessed. Second, the value of these resources must be recognized and converted to cultural capital. Finally, this cultural capital must be activated or invested, so a social benefit or profit is produced (page 179). This process implies that individuals have differential access to culturally valued resources. Gatekeepers, through micropolitical processes likely shaped by race and class, evaluate these resources. For example, Roscigno and Ainsworth-Darnell [42] showed that despite controls for socioeconomic status, Black students received less returns for their cultural capital than White students. They argue that "much research has overlooked the important micropolitical processes that occur in schools and classrooms that may have consequences for whether cultural capital... functions similarly... for Blacks and Whites" (page 159). Such micro-political processes are played out in educational settings that are not neutral institutions but instead political organizations that reproduce existing inequality by privileging the elite norms. These processes may reward norms that more closely comply with the standards of the institution. In fact, Washington [19] found that Black students' lack of support from school personnel is the largest factor contributing to low participation in study abroad, a finding consistent with those of other studies that examine minority underrepresentation in study abroad (see $[1,25,26])$.

Reports suggest that study abroad programs may have standards that disadvantage Blacks more than Whites [3]. That is, criteria that seem "normal" or "typical" to recruiters, may unintentionally disadvantage Blacks. Fordham [43] found that the process of choosing students for study abroad was implicitly culturally biased in favor of White middleclass students. She found that recruiters assumed that applicants possessed specific cultural capital, namely, that they participated in extracurricular activities and came from "well adjusted" nuclear families, who lead active social lives in clubs and society. This assumption disadvantages students who work and thus don't have time for extracurricular activities. In general, Black and/or low socioeconomic status students are more likely to have multiple jobs, to come from families who are less financially stable and who have not traveled abroad. Thus, school personnel are less likely to see Blacks as "typical" American college student [23, 43].

Class and race can also shape the ability of student and parents to negotiate advantage for themselves [37, 44]. Lower income and minority students are less likely to have a "natural familiarity" about how to comply with institutional standards that privilege the norms and values of the White elite [38, 45-47]. Educational research reveals that social relationships between minority youth and "institutional gatekeepers" (school personnel, advisors, and recruiters) are "often marred by social distance and distrust" [36]. Students must have a level of comfort to approach faculty and staff about study abroad, and they must have a "familiarity with communication channels for the transmission of information" [47]. But not every student is equipped with the cultural repertories (or cultural capital) considered normative in institutions of higher education.
3.5. Institutional Factors. Beyond the micro-political processes that affect class and racial access to study abroad opportunities, programs may be organized and staffed in ways that also shape participation. For example, Carter [3] found that university administrators believe Blacks are only interested in going to Africa and have little inclination to go to Europe. However, study abroad programs are much more likely to take place in western European countries that are more closely aligned to the history and interests of White, middle-class students [3]. In short, destination choices may be determined in a biased way that results in fewer minority and/or poor students taking part. Carter [3] also argues that minorities are underrepresented in study abroad recruitment faculty. She claims that this lack of minority staff sends the subtle message to minority students that study abroad and even future endeavors that require international experience are not applicable to them. As a consequence, these students may be unwilling to share their desire for overseas education with staff they perceive as not understanding their social constraints or goals. This view is echoed by Booker [1] and Washington [19], who reported that students who did not participate in study abroad perceived that faculty and advisors offered little encouragement about international exchange and provided little in-depth information about study abroad to aid them in applying.

\section{Data, Methods, and Analytic Strategy}

The current study addresses these theoretical explanations of race and class disparities in study abroad participation using both quantitative analysis of nationally drawn data, qualitative in-depth interviews of students who participated in study abroad and other students who expressed an interest but did not participate. The qualitative analysis, which was conducted before the quantitative analysis, provides a detailed narrative of the decision-making process and examines how race and class can shape barriers to study abroad participation. The quantitative research examines whether there is a broad trend in how racial groups vary in their study abroad participation, and whether such disparities are explained by measures of habitus, social networks, cultural capital, and family socioeconomic status. The advantage of using a mixed method approach is that it can test the consistency of research phenomena under investigation [48]. It can also provide greater insight and understanding into the topic, since multiple approaches examine varying perspectives.

4.1. Quantitative Data/Analysis. The quantitative component of the current study uses the National Education Longitudinal Study of 1988-2000 (NELS), coupled with the Postsecondary Educational Transcript Study (PETS). This study surveyed a nationally representative sample of eighth graders in 1988 and followed them until 2000 when they were eight years beyond high school. The sample includes 8,822 students from the original NELS sample who attended college and whose postsecondary transcripts were collected for the PETS study. ${ }^{3}$ Among this group of college students, 308 participated in study abroad while in college. Theoretical 
processes implied by past research on study abroad and our qualitative analysis guide the analytic strategy detailed below.

Study abroad participation was measured using students' postsecondary transcripts and indicates whether the student received college credit for studying abroad (see Table 1 for a detailed description of all variables used in our analysis). We gauged habitus using two measures: "parents' nativity" and "family vacations." "Parent's nativity" is a dichotomous variable indicating whether at least one of the student's parents is foreign born. "Family vacations" indicates how frequently students took day trips or vacations with their parents during their senior year of high school. Ideally, we would be able to restrict this measure to trips abroad, but we are unable to do so because of data limitations. Our social network variables include "intergenerational closure" and "peer support for education." "Intergenerational closure," a commonly used measure of social networks among parents of school-aged children, refers to the number of their children's friends' parents a parent knows [49]. "Peer support for education" determines if the student's friends have pro-school attitudes [50].

Cultural capital is measured using four indicators: "extracurricular activities," "goes to museums," "goes to extra classes," and "household educational resources." While these indicators are admittedly not ideal, in as much as they are not directly connected to internationalism or the ability to negotiate advantage in an educational setting, they do capture a general engagement in mainstream educational processes and are factors that are likely to be positively evaluated by study abroad recruiters, as discussed above. "Extracurricular activities" measure the number of activities the student was involved in during high school, a factor shown to enhance educational outcomes [51]. "Goes to museums" and "goes to extra classes" indicate involvement in nonschool activities that have been shown to benefit students and magnify race and class disparities [42, 52, 53]. Finally, "household educational resources" represent an indicator of objectified cultural capital $[30,40]$ that has been shown to benefit students educationally [54].

We use these and other independent variables in logistic regressions to predict college study abroad participation. Specifically, we regress study abroad participation based on student race, gender, family characteristics (including socioeconomic status), and measures of habitus, social networks, and cultural capital. We expect the following groups to be less likely to participate in study abroad: (1) racial minorities; (2) students without a personal and/or family habitus that promotes travel and internationalism; (3) students with smaller, less proschool social networks; (4) students with less cultural capital; (5) students with lower socioeconomic status. We will also test whether racial disparities in study abroad participation are explained by racial differences in habitus, social networks, cultural capital, and socioeconomic status. Finally, we test whether the process leading to participation is different across racial groups by examining racial interactions with all significant predictors of study abroad participation.

4.2. Qualitative Data/Analysis. In order to understand the mechanisms that reproduce racial and class disparities in study abroad participation, we complement our quantitative analysis with twenty-one semistructured interviews. Seidman [55] argues that interviews are the most appropriate methods to help researchers become knowledgeable about individuals' experiences or "stories" in addition to understanding how these persons define their own social realities (i.e., their thoughts and meanings). This qualitative sample includes eleven students who participated in study abroad at university $\mathrm{X}^{4}$ in the last two years (five White and six Black) and ten students (four White and six Black) who either expressed interest ${ }^{5}$ in participating or who applied to a study abroad program at University $\mathrm{X}$ in the last two years (between 2005-2007) but did not participate. ${ }^{6}$ The majority of interviewed students were female. This mirrors the U.S. study abroad population, whereby females account for 65.5 percent of the total $(205,983)$ participants in the United States during the 2004/05 academic year [21]. ${ }^{7}$

Participants were recruited by purposive sampling with a snowballing effect. When participants were recruited, they were asked to suggest other participants who fit the interview criteria. Initial recruitment was done through the directors of various study abroad programs, through email requests, and from flyers distributed in classrooms, dorm rooms, student lounges, and bulletin boards around University X's campus. The interviews ranged from one to two hours each, were audiotaped, and transcribed. We believe the quality of our interview-based data was enhanced by the fact that the first author (who conducted all the interviews) is a Black female who recently navigated the study abroad process and was able to study abroad. The author's positionality and exposure allowed the majority of respondents to talk about their study abroad experiences with ease. This is not to suggest that every respondent was comfortable supplying details about their experiences, especially when questions about race and treatment by faculty during the study abroad process emerged. For instance, one Black female respondent even questioned the author's reasoning for asking questions dealing with race.

When asking for details about the experiences of nonparticipating respondents brought up some very poignant emotions for some these interviewees. Additionally, the author's position as a study abroad program participant may have signaled to those respondents that did not study abroad for financial reasons that the author was "privileged." This perception may have inhibited truthful answers about financial situations or barriers they personally experienced. The interviewer tried to remedy this situation by asking nonconfrontational probing questions that allowed the interviewees greater contextual and conceptual understanding of their situations, while simultaneously maintaining respect and treating the information obtained throughout the interview with sensitivity.

Data were analyzed using Grounded Theory techniques [56]. We rely heavily on the interpretation of grounded theory methods by LaRossa [57]. LaRossa's interpretation of GTM is simplified and methodologically condensed in that it focuses on the basic elements of GTM. These include: the centrality of language, the reciprocal nature of theory generation and words, and the process of coding built upon both conceptual and empirical comparisons, among other 


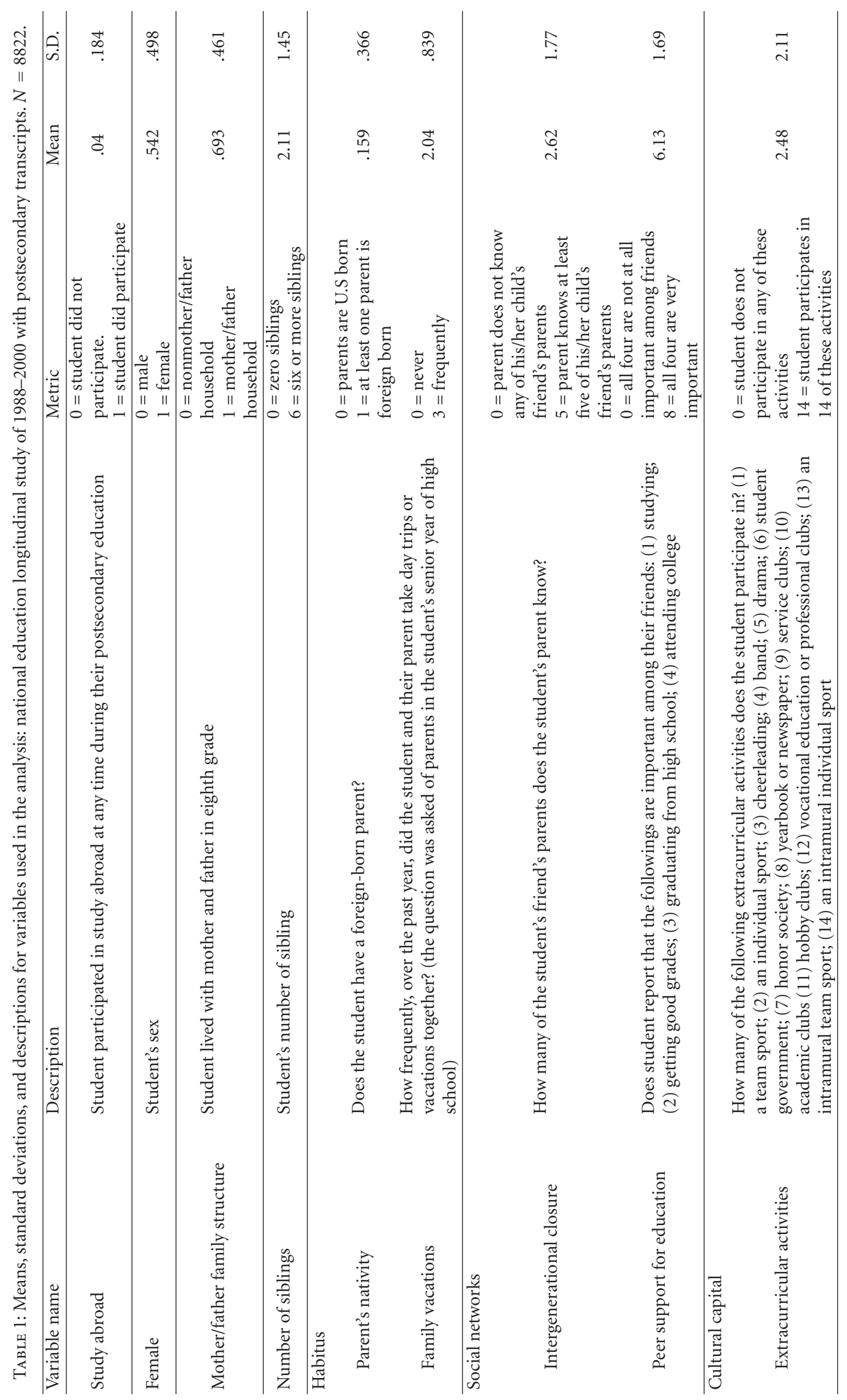




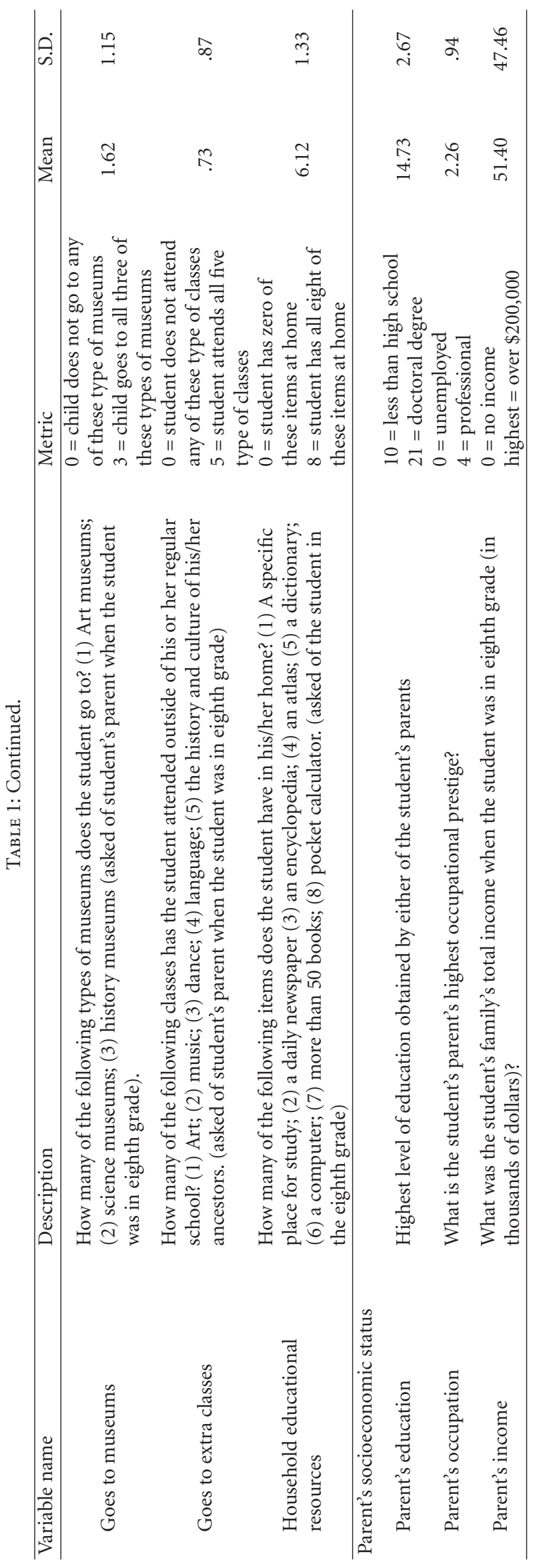


elements (page 838). Although we did not utilize all of the GTM methods since we did not generate a formal theory, we adopted several important features of the method to suit our research, as Glaser and Strauss [56] advocate. To ensure the systematic analysis of the results, we employed the conceptindicator model, which adopts the constant comparison of indictors (or words that represent a concept) so that indictors for concepts are consistently compared with each other [57, 58].

The data analysis process began with open coding, in which we conducted careful line-by-line analysis of all paragraphs of the interview transcripts looking for emerging patterns and themes. For each transcript, we noted and examined words, phrases, sentences, or themes (indicators) about the types and qualities of experiences with the study abroad process. Through axial coding, which involves "developing hypotheses or propositions" [57] and examining how variables that were previously formed relate to each other, we noted that a set of consistently recurring variables (i.e., categories) emerged from the data. Examples of these thematic variables include: types of concerns about study abroad; duration of international exposure; types of travel desires; awareness and perceptions of study abroad; levels of determination to study abroad; quality of information from peers, study abroad office, professors, materials, and so forth; concerns about race related to study abroad; degrees of comfort and intensity of contact with agents and institutional barriers. We noted that a central organizing theme or "story" in the data was the "the use and activation of resources" in the study abroad process, including those resources which relate to the themes of habitus (awareness and perception of study abroad); social networks (quality of information from peers, study abroad office, professors, materials, and so forth); cultural capital (degrees of comfort and intensity of contact with agents). We have organized our discussion of these variables using the preexisting theoretical constructs discussed above (e.g., habitus, social networks, cultural capital).

\section{Results}

In this section, where appropriate, we present a discussion of the quantitative and qualitative findings concurrently. In general, we first present the statistical analysis and then draw on the interview-based evidence to provide a more nuanced treatment of the issue at hand. Prior to this synthesized discussion, we review bivariate analyses of the NELS data that describes racial differences across our dependent and independent variables.

5.1. Bivariate Analysis of Quantitative Data. Table 2 provides an overview of the unadjusted racial differences across the variables used in the quantitative analysis. White and Asian students are more likely to participate in study abroad than are Black and Hispanic students, and this general division is mirrored throughout the bivariate analysis with a few exceptions. Black and Hispanic students have parents with lower education, lower occupational prestige, lower family incomes, and more siblings; they are less likely to go to museums and take extra classes, and they have fewer household educational resources. Blacks in this sample are also more likely to be female and not be in mother/father households. Hispanic students stand out as the group least likely to be involved in extracurricular activities. This general trend does not hold for the measures of habitus and social networks, however. Not surprisingly, it is Hispanics and particularly Asians who are more likely to have foreign-born parents, and White students are the most likely to take family vacations. Finally, White and Black students have the highest levels of intergenerational closure, and Blacks and Asians are most likely to have friends who support education.

\subsection{Habitus: Class and Racial Differences in Dispositions tow-} ard Study Abroad. Before the respondents even conceived of the idea to study abroad, they first had to aspire to travel abroad. A student's disposition toward internationalism-their habitus relative to international interests and outlooks - will likely be profoundly affected by their history of past travel, whether the student or their parents are foreign-born, their socioeconomic status, and perhaps their race. Students whose families travel abroad and are more comfortable with foreign cultures are more likely to see study abroad programs as appropriate for themselves and/or relevant to their educational goals. These expectations are consistent with the quantitative findings reported in Table 3 (Model 2) that both having foreign-born parents $(1.028, P<$ $.001)$ and taking family vacations $(.282, P<.01)$ increase the likelihood that a student will study abroad. Controlling for these two measures of habitus also affect the racial patterns found in Model 1 of Table 3. Asians, who were no different than Whites in their study abroad participation in Model 1 $(-.039, \mathrm{~ns})$, are significantly less likely to participate once the habitus measures are controlled for $(-.809, P<.01)$. This change in the Asian effect is due to their greater likelihood of having foreign-born parents. Similarly, Hispanics are 73\% less likely to participate in study abroad once the benefit of these habitus measures are controlled for (from -.744, $P<.05$ in Model 1 to $-1.287, P<.001$ in Model 2). Finally, Black students do experience a slight $10 \%$ decrease in their likelihood to study abroad (from -.964, $P<.05$ in Model 1 to $-1.059, P<.05$ in Model 2). This minor change in the Black/White disparity in study abroad is expected given the suggestion from past studies that Black students have a prostudy abroad habitus and may in fact be more positively disposed to such programs.

Our qualitative, interview-based evidence echoes these patterns and provides a more nuanced overview of the role habitus plays in shaping study abroad participation. The desire to travel among some of the students we interviewed was fueled by their "global imaginations," a mindset which allowed them to envision life's possibilities beyond their national boundaries [32]. For these respondents, their aspirations can only be achieved by visiting foreign countries. For instance, students mentioned that travel could achieve a multitude of objectives including "seeing something new," "experiencing something different or exotic," "gaining a 
TABLE 2: Means comparisons of dependent and independent variables by race.

\begin{tabular}{|c|c|c|c|c|}
\hline & White & Black & Hispanic & Asian \\
\hline \multicolumn{5}{|l|}{ Dependent variable } \\
\hline Studied abroad & $.04^{\mathrm{BH}}$ & $.01^{\mathrm{A}}$ & $.01^{\mathrm{A}}$ & .03 \\
\hline \multicolumn{5}{|l|}{ Independent variables } \\
\hline Female & $.537^{\mathrm{B}}$ & $.599^{\mathrm{HA}}$ & .549 & .520 \\
\hline Mother/father family structure & $.749^{\mathrm{BHA}}$ & $.458^{\mathrm{HA}}$ & $.704^{\mathrm{A}}$ & .834 \\
\hline Number of siblings & $2.00^{\mathrm{BHA}}$ & $2.44^{\mathrm{A}}$ & $2.54^{\mathrm{A}}$ & 2.14 \\
\hline \multicolumn{5}{|l|}{ Habitus } \\
\hline Parent's nativity (foreign born =1) & $.055^{\mathrm{BHA}}$ & $.086^{\mathrm{HA}}$ & $.475^{\mathrm{A}}$ & .775 \\
\hline Family vacations & $2.07^{\mathrm{BA}}$ & $.191^{\mathrm{H}}$ & 2.02 & 1.94 \\
\hline \multicolumn{5}{|l|}{ Social networks } \\
\hline Intergenerational closure & $2.85^{\mathrm{BHA}}$ & $2.58^{\mathrm{HA}}$ & 2.04 & 1.89 \\
\hline Peer support for education & $6.08^{\mathrm{BA}}$ & $6.31^{\mathrm{H}}$ & $6.07^{\mathrm{A}}$ & 6.47 \\
\hline \multicolumn{5}{|l|}{ Cultural capital } \\
\hline Extracurricular activities & $2.56^{\mathrm{H}}$ & $2.52^{\mathrm{H}}$ & $2.04^{\mathrm{A}}$ & 2.72 \\
\hline Goes to museums & $1.64^{\mathrm{BHA}}$ & $1.46^{\mathrm{A}}$ & $1.50^{\mathrm{A}}$ & 1.74 \\
\hline Goes to extra classes & $.75^{\mathrm{BHA}}$ & $.64^{\mathrm{HA}}$ & $.50^{\mathrm{A}}$ & .93 \\
\hline Household educational resources & $6.27^{\mathrm{BHA}}$ & $5.74^{\mathrm{HA}}$ & $5.45^{\mathrm{A}}$ & 6.15 \\
\hline \multicolumn{5}{|l|}{ Parent's socioeconomic status } \\
\hline Parent's education & $14.96^{\mathrm{BHA}}$ & $14.04^{\mathrm{HA}}$ & $13.17^{\mathrm{A}}$ & 15.65 \\
\hline Parent's occupation & $2.31^{\mathrm{BHA}}$ & $.206^{\mathrm{HA}}$ & $1.84^{\mathrm{A}}$ & 2.48 \\
\hline Parent's income & $53.05^{\mathrm{BH}}$ & $29.72^{\mathrm{A}}$ & $31.09^{\mathrm{A}}$ & 56.35 \\
\hline
\end{tabular}

${ }^{\mathrm{B}}$ denotes a significant difference with Blacks $(P<.05)$.

${ }^{\mathrm{H}}$ denotes a significant difference with Hispanics $(P<.05)$.

A denotes a significant difference with Asians $(P<.05)$.

different perspective about the world," or could be used to "escape from the USA".

Some students were directly exposed to international travel through vacations with their families. The exposure to these experiences cemented the idea that international travel was normative and provided them a first-hand understanding of what overseas experiences entail. Brianna was able to identify the particulars of what she wanted from her travel based on her family vacation to Europe. She states the following:

This summer, I went to Europe and that was fun. I went to Italy and Greece... It was a vacation... However, the way my parents travel is like "let us bring the U.S. to another country.". . So we stayed in American standard of living type places and we did the tourist things... but that's not the way I like to travel. I like to stay with a host family or stay in a hostel and actually get immersed in the culture.

Even though her family stressed the importance of travel, Brianna realized she did not want to Americanize her international experiences. She refined her travel-related habitus, critiqued her past experiences, and decided on what she preferred for her overseas experiences.

For some students, their habitus emphasized a global orientation because of their family's international experiences. As the quantitative analysis shows, students with foreignborn parents are much more likely to study abroad. Patrick got the impression, from his parents' experience of living abroad, that international travel allowed you to become more "worldly:"

My parents were born in England and by default they moved with their parents to Guyana at a young age and then moved back to England so they already have that journey or the willingness to look at new cultures and adapt to new cultures.

Alexis also associated international travel with becoming more "cultured." She developed this impression and desire to travel from her mother's insistence that she visit India.

My mom is not originally from America. I think this allows her to be more supportive of the idea of international travel. She encourages any opportunity that presents itself to help me become more cultured... It is her dream to get me to go to India, where she is from, and experience her homeland.

These examples illustrate the centrality of upper-middle and middle-class narratives of travel in these respondents' lives. In order to be "worldly" and "cultured," one must travel. These hegemonic notions, or the beliefs about how to become "cultured" through traveling, are accepted, validated, and reproduced by their families' cultural backgrounds, lifestyles, overseas experiences, and attitudes towards international travel. These particular families had the ability 
TABLE 3: Logistic regression coefficients of participation in study abroad on race, gender, habitus, social networks, cultural capital, and socioeconomic status. National educational longitudinal study of 1988-2000. $N=8,822$. (Standard errors on parentheses).

\begin{tabular}{|c|c|c|c|c|c|}
\hline Independent variables & Model 1 & Model 2 & Model 3 & Model 4 & Model 5 \\
\hline \multicolumn{6}{|l|}{ Race (omitted category $=$ white) } \\
\hline Black & $-.964 *(.420)$ & $-1.059 *(.422)$ & $-1.071^{*}(.422)$ & $-.998 *(.425)$ & $-.834(.430)$ \\
\hline Hispanic & $-.744 *(.315)$ & $-1.287 * * *(.337)$ & $-1.239 * * *(.338)$ & $-.911^{* *}(.341)$ & $-.593(.348)$ \\
\hline Asian & $-.039(.247)$ & $-.809^{* *}(.294)$ & $-.765^{* *}(.296)$ & $-.975^{* * *}(.304)$ & $-1.156^{* * *}(.311)$ \\
\hline Female & $.659^{* * *}(.146)$ & $.633^{* * *}(.146)$ & $.551^{* * *}(.148)$ & $.439^{* *}(.156)$ & $.575^{* * *}(.161)$ \\
\hline Mother/father family structure & $.657 * *(.213)$ & $.582 * *(.214)$ & $.531 *(.215)$ & $.371(.218)$ & $.271(.222)$ \\
\hline Number of siblings & $-.084(.053)$ & $-.077(.053)$ & $-.071(.053)$ & $-.026(.054)$ & $-.013(.056)$ \\
\hline \multicolumn{6}{|l|}{ Habitus } \\
\hline Parent's nativity (foreign born $=1$ ) & & $1.028^{* * *}(.202)$ & $1.046^{* * *}(.203)$ & $.942^{* * *}(.206)$ & $.820^{* * *}(.212)$ \\
\hline Family vacations & & $.282 * *(.092)$ & $.246^{* *}(.093)$ & $.149(.095)$ & $.043(.098)$ \\
\hline \multicolumn{6}{|l|}{ Social networks } \\
\hline Intergenerational closure & & & $.119 *(.048)$ & $.055(.049)$ & $.017(.050)$ \\
\hline Peer support for education & & & $.152^{* * *}(.048)$ & $.091(.048)$ & $.070(.050)$ \\
\hline \multicolumn{6}{|l|}{ Cultural capital } \\
\hline Extracurricular activities & & & & $.107^{* * *}(.032)$ & $.087 *(.034)$ \\
\hline Goes to museums & & & & $.212 * *(.069)$ & $.135(.070)$ \\
\hline Goes to extra classes & & & & $.347^{* * *}(.068)$ & $.182 *(.073)$ \\
\hline Household educational resources & & & & $.244^{* * *}(.067)$ & $.063(.070)$ \\
\hline \multicolumn{6}{|l|}{ Parent's socioeconomic status } \\
\hline Parent's education & & & & & $.121^{* *}(.038)$ \\
\hline Parent's occupation & & & & & $.371^{* *}(.120)$ \\
\hline Parent's income & & & & & $.004^{* * *}(.001)$ \\
\hline Constant & $-3.951 * * *(.252)$ & $-4.586^{* * *}(.323)$ & $-5.790 * * *(.446)$ & $-7.536^{* * *}(.599)$ & $-8.702 * * *(.706)$ \\
\hline Nagelkerke $R^{2}$ & .031 & .051 & .062 & .116 & .176 \\
\hline
\end{tabular}

${ }^{*} P<.05{ }^{* *} P<.01{ }^{* * *} P<.001$.

to reproduce privilege by passing on the advantages of international travel to their children and, in turn, shape the children's habitus [31, 47, 59].

A students' socioeconomic status can also shape their habitus related to study abroad and internationalism in general. For example, Brianna acknowledged the role family class position played in the reproduction of values and attitudes about study abroad by using her own family and friends as examples:

Rich kids, they go and look for it [study abroad opportunities] because like my parents, Fiona's [a friend] parents told her that she needed to study abroad and Stacy's [friend] parents told her that she needed to study abroad. It's a focus on education and not only on education but in-depth education... People who are encouraged and have been pre-exposed [sic] to the idea of study abroad because if someone had never heard of study abroad and came to this university, chances are they could leave the school still having never heard about study abroad. So, I think people find it who look for it, who already know about it.

We can see that Brianna's social network is made up of peers who occupy the same social class standings and received similar messages from their parents about study abroad. Conversely, those respondents who had minimal exposure to study abroad had very different perceptions of it. Natasha perceived study abroad as an expensive activity that only the more affluent in society could afford. Since she did not think she had enough discretionary income to put towards study abroad, she imagined that it was beyond her reach. She recalls:

I had assumed that I was too broke to go ever go on study abroad. Growing up, I always imagined that was something that rich people did, something in the movies. Usually it's people that are well off who are going on study abroad you know, that's something that rich people do, they go backpack through Europe when they graduate high school or college.

However, international travel, having foreign-born parents, and higher socioeconomic status were not the only factors that shaped students' habitus. For some, race also plays a role $[37,45,46,59,60]$. Tiffany mentioned that her peers and mother got the impression that study abroad was "something White people do" and beyond her reality. She recalls:

In high school, they had an exchange program and it wasn't even an option for me to go. It's funny, I tell her [my mother] all the time, I feel like a lot of 
White parents encourage their kids to go abroad, cause they backpacking and stuff. So I think for her its like, what? What is it? Why do you want to do this? I feel like a lot Black people just don't engage in that kind of stuff. We're just kind of like, that's a White thing to study abroad, that's a White thing to travel.

Similarly, Alexis, a black female, first heard about study abroad opportunities from friends and through promotions in her Spanish classes, and she believed that people engaged in study abroad to learn a foreign language. Because Spanish was not her major, she got the impression that study abroad could not be applied to her major areas of interest. Additionally, she presumed it was very expensive. She describes her initial feelings towards study abroad, when she was asked what got her interested in it:

I wasn't even really thinking about studying abroad, I had a negative perception of it. I thought it was going be a big waste of money. I thought the price was going to be ridiculous. I did not think it was going to be worth my money. My scope was narrowed to only seeing study abroad as a way to travel overseas and learn another language. Honestly, I never really thought about study abroad as encompassing a pool of other subjects that could, in fact, be ten times more interesting and or relevant to what I am truly interested in.

Blacks who studied abroad were more likely to have foreign-born parents than Whites who studied abroad, a pattern also found in our quantitative sample. For Blacks who are not children of immigrants, their international worldview was likely fostered through extrafamilial contacts, such as at school or in college. This is because most Blacks who were not children of immigrants had never experienced international travel or had negative perceptions of it as "unsafe" and "a waste of time." In short, their habitus was less likely to promote study abroad participation. This variation in habitus is closely connected to the students' social networks.

5.3. Social Networks: How Family and Peer Networks Shape Study Abroad Participation. Research suggests that there is an important influence of family and peer social networks in providing valuable knowledge-based information that motivates study abroad involvement $[6,19,23]$. This expectation is supported by Model 3 of Table 3, in which we find that intergenerational closure $(.119, P<.05)$ and peer support for education $(.152, P<.001)$ are both significant predictors of study abroad participation. Below we examine our qualitative data to learn about how family and peer social networks impact the study abroad process.

Socioeconomically advantaged White students are more likely to come from families with a tradition of study abroad participation $[4,61]$. This fosters a valuable resource-an awareness and knowledge of study abroad opportunities. For instance, the majority of Shannon's family members participated in study abroad and were able to provide direct knowledge about its benefits and advantages. When asked what her family told her about study abroad, she replied: "all of them [family members] are really positive about it [study abroad]; they said that it was best thing they've ever done, and that no matter what your field of study, going abroad gives you a different view of it." Family members also helped some respondents to better evaluate their program choices. For instance, Ann's mother studied abroad in London while she was in high school and offered Ann advice on how to choose a program. Ann states the following:

Mymother's supportand speaking about her expe-
riences abroad in addition to my previous trip
encouraged me to research what programs were
available through the university and which of
those programs would fit with my interests and
major requirements... she was the one that really
pushed in the right direction to go ahead and sign
$u p$.

Like Shannon, Brianna had several family members who studied abroad while in college and, like Ann, was "always encouraged to study abroad." But verbal encouragement and advice were not the only support her parents provided. When mentioning her parents influence, she stated: "[they said] this is the only time in your life that we're going to pay for your travel, and you know it's a really great advantage because you don't have anything tying you down like a family or a job." In this case, she enjoyed the benefits of limited fiscal responsibility. In fact, when attending freshman orientation on campus, her father pointed out the study abroad promotion booth and reminded her to consider studying abroad.

While Black respondents' families were also enthusiastic about their family member's study abroad plans, they were less likely to provide respondents with any practical assistance when searching for programs. Rather, as in the case of Maxine, a Black female, the nature of their support was often limited to verbal encouragement.

\section{Interviewer: So how did your family respond to your decision to study abroad?}

Maxine: Hey baby that's good, you can do it, you can do it. I mean, they ain't got nothing to contribute.

Interviewer: What do you mean by nothing to contribute?

Maxine: I mean like money, information...

Beyond family social networks, peers also proved to be valuable sources of information about study abroad opportunities. Marie, a White female, was interested in studying journalism in England. Fortunately for her, she had friends who were also journalism majors and studied abroad in England through a company called "World Citizens." Because of 
these associations, she was able to solicit details about the program and school in England:

I had a friend who went through the same program a semester before me. He also goes to this university and went through "World Citizens" to London, to the same school. He said that it was an absolute blast. Most people that I talked to did not say as much about it being academically challenging as much as really opening their mind to a lot and just being a really amazing experience...

Similarly, Brianna gained information about the application process from a close friend:

My best friend "Fiona" is studying abroad, she goes to this university but is studying abroad through the University of Colorado [program] in Paris... I would hear about when her application was due or recommendation or whatever. I mean, I know that you have to apply and I know that, at this university, you have to take an [sic] [information] seminar...

Rachael, a White female, also highlighted the importance of peer advice in the study abroad process:

A really good source [of information] is to hear from somebody who's done it and find out how they did it, who they did it with, how they got their money, how did they credits transfer, which classes did they take, did they stay with a family... Yeah definitely like word of mouth, just students in general.

Unfortunately, lower class students and Black students without a foreign born parent are less likely to have social networks with study abroad experience and therefore are less likely to be exposed to the valuable information and advice they provide. One of the possible reasons for this inequality in the peer networks may lie in the fact that Black students are more likely to have racially similar individuals in their peer networks than White students $[62,63]$. Because Black students are less likely to study abroad [21, 23], their social networks would be less likely to include persons who studied abroad. This limitation resulted in one respondent creatively attempting to understand what life was like for a Black person living in Russia. Antonio did not have any Black peers who traveled there before so, based on the recommendation of his father, he joined an online forum called "Black Russia" in which Blacks who lived or traveled to Russia could share their experiences. This example speaks to the lengths minority student may go to understand the study abroad process.

5.4. Institutional Processes: The Effect of Study Abroad Destination Options. Because the majority of the study abroad program choices are situated in Western Europe [2, 3, 19, 64], students with no interest in European culture and heritage have fewer program options. Whites, therefore, profit from hidden institutional benefits more than their
Black counterparts [65]. But the focus on Western Europe is not the only way White students are advantaged. Students' level of comfort may also be shaped by the destination society.

For example, Ann acknowledged the importance of "blending in" as a reason why she chose her program. When questioned about why she chose a Western European destination, she mentioned that she felt "very comfortable around the native Western Europeans," and that she could "just be herself" in that environment. These feelings of comfort with destinations that are culturally similar to their own is a sentiment voiced by some Blacks who consciously choose programs in Africa and the Diaspora in order to explore their heritage $[64,66,67]$. For example, Carla, who studied abroad in Ghana, highlighted a cultural connection as the reason she chose a location with a strong African influence such as Salvador de Bahia in Brazil:

\section{My own reason for going to Brazil kind of was the reason that I went to Ghana [a previous study abroad destination]... I was like, ok where do I go next? Then I found out about Brazil and its cultural connections to Africa and exactly how strong they were and so that's why I went to Brazil...}

Therefore, students strive to experience commonality and avoid "otherness" and "hypervisible" during their study abroad experiences, a privilege not as readily conferred onto Blacks whose heritages were hardly represented in the traditional program options.

Relatedly, Tiffany's past discomfort in a largely non-Black country compelled her to choose a program location with a sizable Black population for her second study abroad experience. She previously studied abroad in Mexico, but because of the racism she was subjected to, she faced varying degrees of discomfort:

I was definitely the Black girl, and everybody in Mexico, even though they were Mexican, were like White people, they almost did not have an ethnicity, they were like White people who spoke Spanish. I felt like I was around a whole bunch of White people. And I just don't like to be around a whole bunch of White people all the time. It's definitely uncomfortable and somebody always says something stupid and it's hard for me to relate to people who don't get me, and my hair, and the way I talk, and all that stuff. When I was in Mexico these little kids kept coming up to me. I had braids, and they kept trying to touch my hair. And one guy kept talking about Snoop Dogg to me and I was like, "All Black people don't listen to rap music, I don't like rap music, that's not my thing."

5.5. Cultural Capital: Micro-Political Processes and Disparities in Study Abroad. Our general quantitative analysis of cultural capital suggests that it importantly predicts study abroad participation. Model 4 of Table 3 introduces four cultural capital measures into the analysis, and all of them are significant and positive predictors of study abroad 
participation. Specifically, extracurricular activities (.107, $P<.001)$, going to museums $(.212, P<.01)$, going to extra classes $(.347, P<.001)$, and household educational resources $(.244, P<.001)$ were all associated with a higher probability for study abroad. It is also important to note that with these four factors controlled for, "family vacations" and both measures of social networks, are reduced to nonsignificance. This suggests that the value of protravel habitus and social networks is associated with the types of activities and objectified cultural capital that students are exposed to. The impact of these four measures is also demonstrated by the near doubling of the Nagelkerke $R^{2}$ statistic (from .062 in Model 3 to .116 in Model 4), a proxy for the amount of variance explained by the set of independent variables.

Turning our attention to our qualitative findings, we found that many students credited institutional agents (professors, administrative staff, study abroad staff, and academic advisors) with motivating them to consider study abroad. But these agents did not help all students, and the quality of such interactions shaped ease of navigating the study abroad process, and whether students participated. For example, Natasha explained how her professor helped her see that study abroad was something that she should pursue.

\begin{abstract}
Natasha: Growing up I always imagined that it was something that rich people did! When my professor was talking about it, it just sparked my interest and I decided to figure out if I could find a way to do it. And I did!
\end{abstract}

\section{Interviewer: And what did your professor say to convince you to go?}

Natasha: Basically that you can get student loans, you can find grants and that there are ways to make it happen... whether it's having your own fundraiser or whatever, she let me know that it wasn't out of my reach.

She went on to explain the benefits of her relationship with this professor, and how it helped her beyond the information received from the Study Abroad Office.

Dr. Pearson was the biggest help in all of this, she really was the one that talked me through everything and so everything, they told me at the Study Abroad Office was stuff that I'd already been told by Dr. Pearson. For me, I wouldn't say that it [the information session at the Study Abroad Office] was that helpful, but for other students, I would probably say it would be helpful, especially if you don't have a relationship with a professor to just walk you through it, then it is probably very helpful to other people.

This example shows that having a close relationship with an institutional agent can prove instrumental in navigating the study abroad process. Another student, Tiffany, revealed her "strong tie" with a professor:

Tiffany: Going through her [the professor's] program is easy because you could easily work with
her...[When] I found out about it [the study abroad program] I just kept up with "Dr. Pearson" about it. She kept me updated about what was going on and about what I'd be doing.

\section{Interviewer: How did she keep you updated?}

Tiffany: Email. I would talk to her in class or she would call me or I would call her, just like that, so I knew I was going... But me and her got really cool and she told me all about it so...

Interviewer: What do you mean by really cool?

Tiffany: We hang out, I definitely consider her to be my friend, she's just a really nice person. I can have conversations with her about race without her tensing up. That makes me comfortable with her and I trust her to do a good job with me.

This relationship with a professor whom she "would call," and "hang out with"-a friendship with someone she could "trust," and felt comfortable talking with about race-allowed the formation of a close and emotionally supportive relationship. In this case, the relationship crossed the White/Black racial boundary. Unfortunately, this type of connection rarely develops between minority students and White agents, due to a lack of cultural competence between the two parties $[62,68-71]$.

Instead, White students are more likely to form such relationships. Among our respondents, Whites were more likely to report that their exchanges were productive, and that they perceived locations such as the study abroad office as "warm," and "cozy." They were not hesitant to talk about their concerns with finding programs, and no White students reported that their race was a concern for them, even when they considered studying in predominantly non-White nations such as Chile, Brazil, and Egypt. This demeanor is consistent with the literature on "Whiteness," whereby it is considered an "unmarked norm." That is, Whites don't even acknowledge their race in a majority of situations. By contrast, race is "hypervisiable" for minorities [63, 72, 73]. "Whiteness" is a resource because being White smoothes exchanges and interactions with same-race agents [38].

Some Black students, on the other hand, faced obstacles that kept them from developing relationships with institutional agents. Foremost among these was a feeling of discomfort when asking for help [71, 74-76]. Most Black respondents mentioned that they felt "uncomfortable" asking agents questions, especially when it came to the issue of race. For instance, even though Antonio got along well with his Russian professors, he felt uncomfortable discussing how he may be treated as an African American male in Russia:

I didn't feel comfortable discussing the race thing with them [professors]. I mean I've hung out with my Professors before. We've gone to restaurants. We've had dinners together. I've even been invited, one time I was personally invited over Spring Break to go to dinner with the teacher. I feel like 
a teacher's pet. I didn't know if I should go, but I went, and they are all very enjoyable people outside of the classroom. When you go out to eat dinner they're all normal. But because they're native Russian I don't think they could offer the proper [racial] perspective that I need. You can only get that from somebody else who has been through it.

Similarly, Allison grappled with whether to ask her professor about the racial issues she might experience as a Black woman in Brazil and Argentina, because she thought the classroom space was not conducive to raising such a topic:

Interviewer: To what extent did you voice concerns to your professor about how you would be treated as an African American woman for instance, in these two countries?

Allison: I was kind of hesitant to ask. I'm just too tentative to ask that question because I thought I would be really stepping out of the bounds. I guess [it] depends on the type of study abroad trip. I was looking at the significance of actually talking about that [racism].

Even though race is "hypervisiable" for racial minorities, Antonio and Allison basically ignored their racial identities $[77,78]$. These students' discomfort when discussing race with agents is not unique. College campuses in the U.S. are rife with institutional racism that can prevent race issues from being openly discussed [79-82].

For many students, the university bureaucracy was intimidating and they found little help from institutional agents. For example, Ricardo, a Black male, was met with cold, unhelpful responses:

One professor in my department I went to, he's totally wiping his hands of it [study abroad]. He's, like, just go and pursue it. Go to the [study abroad] office and investigate it on your own. Dr. "Maxwell," a professor of Spanish I had that semester, was not really at all trying to be a part of whatever. Pretty much it was independent. It's available [programs], but you have to pursue it on your own.

Despite Dr. Maxwell's knowledge of the availability of Spanish programs, he was indifferent to Ricardo's requests for advice on who to contact or where to access information. Shannon, a White student, also struggled to find help from institutional agents as she attempted to navigate the university bureaucracy:

Interviewer: So what influenced your decision to not go on this program?

Shannon: Well, partially the fact that I didn't feel I could get a straight answer from anybody. I went to my faculty advisor in the department and he said, "you have to go talk to the academic advisor" and then I went to the academic office and the new Italian advisor did not have any idea. The head advisor was like "No, you're department has to do this," so I went back to my faculty advisor who's like "well I can clear you for these two hour credits, but when I went back to talk to the academic advisor they were like, "well you have to talk to the program and blah, blah, blah."

Interviewer: So are you saying you couldn't find anyone who could guide you on what to do?

Shannon: Yeah, I couldn't find anyone who was like "Oh I've done this, we've taken care of this before." It was just like these people were as lost as I was. "I can say this tentatively but I cannot give you a real answer..."

This lack of responsiveness was part of a broader a racialized trend. For example, Carla, a Black female, felt that both her department and the study abroad office were not conducive spaces to discuss her interests. She mentioned that they seemed to have little interest in working with her and casually "pointed to some random materials." She interpreted their "help" as "cold," signaling detachment and disinterest $[82,83]$. Carla believed this approach was representative of the university's superficial attitudes towards multiculturalism and discomfort with race [45]. She believed that these agents kept her from successfully navigating the study abroad process, and their action created more social distance between students and agents.

Conversely, when Shannon, a White female, sought advice on choosing an appropriate program, she displayed the "right" cultural signal and thus easily complied with the agents' standards. ${ }^{8}$ The agent recommended a variety of Italian programs, and so her resources were legitimized and converted into cultural capital. Upper- or middle-class families, are more likely to possess such cultural know-how or have a "natural" familiarity with what Delpit [84] refers to as the "culture of power" (page 39). Such understandings ease interactions with institutional agents.

Students who felt agents invalided their cultural capital chose programs that did not satisfy their interests, or tried to find programs by themselves with varying degrees of success. Louis, for example, a Black male, approached his academic advisor "in a serious way" to learn more about study abroad. He said they mainly discussed whether study abroad would interfere with his graduation schedule, and whether he would be able to transfer credits. This interaction bordered on discouragement, and ultimately Louis did not participate. Overall, students' ability to successfully plan for study abroad programs are linked to the interactions they have with institutional agents. Tiffany for instance, discussed the intellectual resources she was able to obtain through her "strong tie" with her professor [69]:

Interviewer: When you decided to apply to this program what was the application process like?

Tiffany: I think when you work closely with a program director you're fine... 
Interviewer: What do you mean work closely?

Tiffany: She just told me what to do and I did it. If I had any problems I could call her or go to her office, so it was just really easy because I just gave her what she needed. If she needed something else she would let me know. So it was just easy. I think going through her program is easy because you could just easily work with her. I think some program directors can make it really easy and really hard for students. She just kept up with me on my forms and stuff like that to make sure that I gave her what she needed.

Tiffany made strategic use of her cultural capital when she called or went to her professor's office with problems. She got help filling out passport documentation and other required forms. She also realized that she was privileged compared with other respondents. Her statement that "program directors can make it really easy and really hard for students," underscores the importance of gatekeepers in removing barriers or simplifying bureaucratic procedures [71]. For these barriers to be removed, relationships "based on trust and understanding" have to develop between agents and students $[36,71]$.

Students also benefited from a sense of entitlement that likely flowed from their social statuses (such as race, class and gender). For example, Howard, a White male, felt comfortable around agents and easily elicited help from them:

\section{Howard: I asked [professors] for help. Most people don't. Or they don't know that they can. If I run into a problem then I don't try to solve it by myself. I try and find the people who are most knowledgeable... I don't need encouragement.}

Howard acknowledges that the bureaucratic nature of the study abroad process is a microcosm of the wider university environment. Because the university is large and bureaucratic, it requires knowledgeable agents to help students understand "the rules of the game" [59].

\begin{abstract}
Howard: It's [the school system] a bureaucracy. It's a very big bureaucracy. It works, but it works because you have people that will intervene and help you. And if you did not have those people intervening and not doing their job, then you wouldn't get anywhere.
\end{abstract}

Howard's comments are significant because he alludes to two important trends found repeatedly in social reproduction literature. First, there are specific rules governing fields of interaction, and the activation of cultural capital is considered natural and universal by those who possess it. However, this understanding is emergent through their habitus; the fact that asking for help and receiving it is perceived as possible. Without institutional maps to help navigate the bureaucracy, students may get lost and eventually drop out of the process $[47,59,60,71]$. Secondly, Howard mentions that all he had to do was "ask for help" to remain on track. His flippant response suggests he underestimates the difficulties of accessing agents' help, which can be problematic for people who don't have strong ties with institutional agents. Students need to develop supportive relationships with agents in order for resources to be transmitted [36, 71]. However, for Black respondents especially, developing these relationships take special efforts. They need to gain trust and feel comfortable with agents-a process that can be difficult, especially if their experiences with the institution have not been favorable.

5.6. Financial Considerations: How Access to Money Shapes Study Abroad Participation. As discussed, social class can shape a student's habitus, affect social networks, and influence micro-political interactions with institutional agents. The socioeconomic status of a student and his/her family, can also have a direct impact on the ability to pay for study abroad. To quantitatively examine the role of socioeconomic status on study abroad participation, we added three measures of parent's socioeconomic status (parent's education, parent's occupational prestige, and parent's income) to Model 5 of Table 3. Each of these three measures are positive and statistically significant predicators of study abroad participation $(.121 P<.01, .371 P<.01$, and $.004 P<.001$, resp.). The inclusion of these measures also results in interesting changes to the predictive power of other independent variables. First, Black and Hispanic students are no longer statistically less likely to participate in study abroad once socioeconomic status is controlled. This suggests that key racial disparities in study abroad participation are linked to differences in parents' level of education, their occupational prestige, and their family income. Second, the predictive power of two cultural capital measures ("goes to museums" and "household educational resources") are also reduced to non-significance. This suggests that wellto-do parents are more likely to make these investments in their children, and that these factors are not important predicators of study abroad participation above and beyond parents' socioeconomic status. Three theoretically motivated variables do, however, remain significant predictors of study abroad participation, even when controlling for parent's socioeconomic status ("parent's nativity," "extracurricular activities," and "goes to extra classes"). This suggests that students' habitus and cultural capital can influence study abroad participation independent of their socioeconomic status. Finally, the importance of these socioeconomic status variables is further demonstrated by the largest increase in the Nagelkerke $R^{2}$ statistic (from .116 in Model 4 to .176 in Model 5) of any Model.

Lastly, an important general finding from our quantitative analysis is that the overall process leading to study abroad does not seem to vary by racial group. To test the possibility that the process is different across races, we added race interactions with all significant predictors in Model 5 (results not shown). None of the interactions were significant. This implies that students of all these racial groups receive equal returns to their habitus, social networks, cultural capital, and family socioeconomic status. 
Our qualitative evidence also speaks to how socioeconomic status influences study abroad participation. As discussed above, some researchers downplay the impact of financial constraints because of the availability of scholarships, grants, and student loans that can help students realize their desire to study abroad. But the school-based scholarships at the university under consideration typically only ranged from $\$ 250$ to $\$ 1,000$. Many students viewed this as too little to impact their ability to participate.

The frustration of not being able to fund study abroad programs is exacerbated by a consistent message that funding sources are widely available. Maxine's professor would tell her that "aid was out there," but she lacked specific information on how to access this money:

People tell you what they know to tell you, "there's money out there!" you just got to find it. Tell me where the money is! Tell me, because I was on the Internet, I did not even have Internet access, I was up here [at school] on the Internet for hours, every week [looking for money].

Even though Rachael critiqued this rhetoric, she still bought into the promise of finding funding:

They [agents] say there's a lot of study abroad money, like aid out there... that's what I hate, I hate hearing, like "Dr. Ortiz" has told me this a hundred times, there's so much money out there, they have more money, they don't even know what to do with it. So why don't they give it to me! How do I get this money? I want specifics. I want to know. Tell me what to do and I'll do it!

In actuality, the pool of scholarship money to fund study abroad is limited nationwide $[19,23]$. This requires lower class students to find innovative ways to fund study abroad, such as personal fundraising, taking out loans, or paying for it with credit.

Most of the students turned to their parents for financial assistance, but lower class families had fewer resources to help. For students with well-to-do families, this was often not a problem. Brianna said her parents promised to pay for her entire trip if she decided to study abroad:

Brianna: I wouldn't pay for it [study abroad], I wouldn't have to worry about it. My parents would pay for it. I wouldn't have to worry about the cost or taking loans or anything...

Interviewer: How do you know that your parents are going to pay for it?

Brianna: They told me. I think they know that they really want me to go, and they know that if they don't pay for it that the chances of me going are much lower, so if they want me to go they don't really have a choice.

For the majority of respondents, family members offered to pay a portion of their expenses, but few were as fortunate as Brianna. Consider Rachael, who struggled to find financial aid, and could not depend on her family to help defray the cost. She had to financially support herself "from the time [she] was 18" and knew "it was only natural to pay for college [her] self." Rachael was stuck trying to find funding and considered using student loans to study abroad. However, because she did not want to incur additional debt, loans were a last resort for her. ${ }^{9}$ Financial inequality in access to study abroad was obvious to Rachael, who reflected on the types of students she met at the information session at the study abroad office:

I really, really want to study abroad, I really do [need to study abroad], I'm in international business, I need it. And then there are so many people who don't really need it, they're just kind of doing it for a vacation. They'll go on this threeweek summer programs and think its fun, and I think its great that they do it, but I'm saying I wish there was more money available. ... It just does not seem fair.

Other students employed a variety of strategies to finance their study abroad program when they realized that despite having scholarships and loans, the cost to study abroad was still out of reach. Maxine's family could not contribute funding for her expenses. When she found that the program to France would cost nearly $\$ 15,000$, she tried to activate her cultural capital. To lower her program fees, she suggested staying with a family she knew in France instead of in the required dorm. Her creative suggestion was rejected. Additionally, Maxine worked as a waitress and asked for a cash advance from her boss, which was also denied (unlike Catherine, whose boss did give her a cash advance to go abroad). She even mentioned that she was thinking of "becoming an egg donor and stopped smoking for three months" to try and amass enough money to study abroad. Ultimately, she decided against taking such a drastic step. Because she lacked financial capital, Maxine ended up foregoing the program and did not study abroad. Not surprisingly, having access to financial resources significantly shaped students' thoughts about whether studying abroad was possible, and, in the end, whether they actually participated.

\section{Conclusions}

Our results suggest that race and class significantly shape the process leading to study abroad participation. These findings are important because study abroad participation has been shown to have meaningful impacts on cultural $[4,8,9,12]$, and labor market outcomes $[15,16]$. Over time, the value of international experience will likely grow due to globalization. Opportunities such as study abroad may increasingly reproduce class and race inequality in education and beyond. In this current study, we examined the process leading to study abroad participation with particular focus on three theoretical mechanisms: habitus, social networks, and cultural capital. 
TABLE 4: Summary of characteristics for interviewed students.

\begin{tabular}{|c|c|c|c|c|c|c|c|c|}
\hline Pseudonym & $\begin{array}{l}\text { Participated } \\
\text { in study } \\
\text { abroad? }\end{array}$ & Age & Sex & Race & Father's birthplace & Mother's birthplace & College major & $\begin{array}{l}\text { Student traveled or } \\
\text { lived } \\
\text { overseas before study } \\
\text { abroad }\end{array}$ \\
\hline Carla & Yes & 23 & Female & Black & United States & United States & Psychology & No \\
\hline Rosa & Yes & 28 & Female & Black & United States & United States & Spanish & No \\
\hline Tiffany & Yes & 23 & Female & Black & United States & United States & Anthropology & No \\
\hline Alexis & Yes & 20 & Female & Black & United States & India & Film Studies & No \\
\hline Allison & Yes & 22 & Female & Black & Nigeria & Nigeria & Business & Yes \\
\hline Debra & Yes & 30 & Female & Black & Jamaica & Jamaica & Spanish & Yes \\
\hline Andrew & Yes & 31 & Male & White & United States & United States & Business & No \\
\hline Catherine & Yes & 27 & Female & White & United States & United States & Public Health & Yes \\
\hline Natasha & Yes & 26 & Female & White & United States & United States & Sociology & No \\
\hline Ann & Yes & 22 & Female & White & United States & United States & Hospitality Admin & Yes \\
\hline Marie & Yes & 19 & Female & White & United States & United States & Journalism & Yes \\
\hline Louis & No & 46 & Male & Black & United States & United States & Business & Yes \\
\hline Maxine & No & 24 & Female & Black & United States & United States & Religion & Yes \\
\hline Patrick & No & 20 & Male & Black & England & England & History & Yes \\
\hline Ricardo & No & 32 & Male & Black & Trinidad & United States & Journalism & Yes \\
\hline Antonio & No & 26 & Male & Black & United States & United States & Russian & No \\
\hline Nicole & No & 23 & Female & Black & United States & United States & Accounting & Yes \\
\hline Brianna & No & 20 & Female & White & United States & United States & Anthropology & Yes \\
\hline Howard & No & 50 & Male & White & United States & United States & Math and Swedish & Yes \\
\hline Rachel & No & 21 & Female & White & United States & United States & International Business & Yes \\
\hline Shannon & No & 20 & Female & White & United States & United States & Italian & Yes \\
\hline
\end{tabular}

We found that differences in habitus, or attitudinal dispositions towards study abroad participation are related to past international exposure, social class, and race. Students whose families had lived or traveled abroad were more likely to perceive it as normal and to see the advantages of participation. Socioeconomically advantaged students were also more likely to be involved in study abroad, because they came from families who engaged in concerted cultivation [37]. That is, advantaged students are more likely to have heavily scheduled activities throughout their high school education, and college study abroad is a natural extension of this. Some of the reasons why these disparities in participation existed had to do with a sense of what is normal, or "the natural thing to do." High socio-economic students often saw study abroad as a way to "find themselves," while more disadvantaged students considered it a luxury they struggled to obtain. Specifically, an economically disadvantaged White student described study abroad as "something that rich people did, something in the movies," while a Black student reflected upon a reluctance within the African-American population to participate in study abroad: "I feel like a lot of Black people just don't engage in that type of stuff." While this student perceived a resistance to study abroad in the general African-American population, this sentiment was not widespread in our qualitative sample. Moreover, our quantitative results revealed that once controls for socioeconomic status were included, Blacks and Hispanics did not differ from their White peers in terms of participation in study abroad. Overall, our findings are consistent with Carroll's [2] conclusion that minority students' habitus is not resistant to study abroad.

Unfortunately however, poor and minority students are embedded in social networks that are less conducive to study abroad participation. We found that while they receive verbal encouragement from their families, they are less likely to benefit from material support in comparison with higher socioeconomic status and White peers. This social network disadvantage extends to peer networks as well. Our interview data showed that minority and poorer students were less likely to have friends who had returned from study abroad. These returning students commonly acted as guides and mentors for students interested in study abroad, but they were not equally available to all students.

Micropolitical processes between students and study abroad faculty/staff also affected race and class disparities in study abroad participation (see [42]). Our qualitative respondents pointed out that professors either ease or impede participation. For example, one respondent said "I think some program directors can really make it really easy and really hard for students." Whether students form positive relationships with university gatekeepers is likely dependent upon the cultural capital they activate during micro-political interactions. Differential success in negotiating interpersonal interaction is related to the past research on parental efforts 
to gain educational advantage for their children $[38,44]$. Lareau and Horvat conceptually emphasize "moments of inclusion" (gaining advantage through negotiation) and "moments of exclusion" (unsuccessfully negotiating for a desired outcome) that result from these interactions. Success is more likely when a student is familiar with the conventional "rules of the game", or the prevailing "culture of power" [84]. We agree with researchers who argue that the culture of power should be explicitly taught to disadvantaged students $[46,84]$. Such training could lead to more positive interactions among poor and minority students interested in study abroad.

If positive relationships are to form, however, the study abroad structure and the faculty and staff involved must change as well. First, there may be too few minority faculty and staff participating in study abroad programs. Minority faculty/staff can more easily act as "multicultural navigators" for poor and minority students [45]. Second, increasing the variety of destination choices (to regions beyond Western Europe) likely would increase the number of minority students who participate. Overall, creating a more diverse environment within the study abroad programs would limit the associated reproduction of inequality. Third, misperceptions, such as Blacks' lack of interest in study abroad, and that students interested in study abroad are those who come from "well-adjusted" nuclear families that are heavily involved in extracurricular activities, need to be corrected. Our results suggest that Black students, despite their strong interest in study abroad, often perceive the process as "cold," "distant," and lacking responsiveness to their concerns about potential racism. As long as Whites are made to feel comfortable with the study abroad process (and experience "moments of inclusion") and Blacks remain highly concerned about racism within the process (and experience "moments of exclusion"), disparities in participation are likely to persist [38].

Beyond examining an understudied topic-study abroad-this research makes important contributions in other ways. First, previous studies of micro-political processes related to "moments of inclusion and exclusion" have focused on elementary or secondary students and their parents. The current project studies adult students who must navigate this process largely independent of their parents, and therefore broadens the range of the life course in which these ideas are analyzed. Second, what we learn about this process may shed light on other related processes that take place within institutions of higher learning. How the reproduction of inequality works within study abroad may generalize to other processes in higher education such as: academic mentoring and advisement, achieving leadership positions in student organizations, internships, career counseling, housing and residential life, and financial aid [85]. What we learned about study abroad may also inform our understanding of other adult opportunities beyond the college environment, such as opportunities at work (i.e., promotions) or in voluntary organizations (e.g., PTAs, churches, clubs, neighborhood associations, and political parties). Finally, this paper is an example of how both qualitative and quantitative evidence can be used in combination to examine a research question. Our results reinforce each other while providing a representative overview of predictors of study abroad participation and giving voice to poor and minority students as they strive to participate in study abroad.

\section{Acknowledgment}

The authors would like to acknowledge Leanna Ampola, Mary Ampola, Erin Ruel, and Oswald R. Simon for their helpful comments.

\section{Endnotes}

1. Study abroad can be defined as educational programs that occur outside the geographical, political, and cultural borders of the United States, in which a student may receive academic credit. Moreover, study abroad programs must have an international component, either through "learning in a foreign language, immersion in foreign institutions and/or structured social situations, or rigorous study of international content either in the classroom or outside it" $[86,87]$.

2. Throughout this study, the racial category "Black" will be used to refer to participants of African descent instead of the term African American, so as not to exclude those persons who were born overseas or whose parents were born outside of the United States.

3. Because of their small sample size, sixty-five native American students were excluded from our analysis. Only one of these sixty-five students participated in study abroad.

4. University $\mathrm{X}$ has been operating study abroad programs for over twenty years. Despite a Fall 2006 enrollment of 26,135 students, only 616 studied abroad at University $\mathrm{X}$ during 2006-07 academic year [88, 89]. Minority students comprise only $17 \%$ of the study abroad population in the 2005/2006 academic year, although they comprise $33 \%$ of the study body [90]. University X's program offerings include diverse locations such as South Africa, Sweden, France, Spain, Turkey, Egypt, Mexico, Argentina, and Japan. In order to accommodate the university's nontraditional student body, programs are usually held during the May semester before the official summer semester for two to three weeks. Students also have a choice of going on summer, semester-long or year-long programs. As outlined in University X's most recent strategic plan, exposing students to international perspectives is one of their aim initiatives. In order to make this vision possible and to increase study abroad enrollment, University $\mathrm{X}$ introduced a compulsory education fee, which students pay along with their tuition. These fees are used towards scholarships and aid towards study abroad.

5. We define "interest" as having attended an information seminar at the campus study abroad office, which is usually the first step students take to access information when they make the decision to pursue study abroad. 
6. By focusing on Black and White students, we do not intend to ignore the experiences of other racial/ethnic groups. National figures indicate that Blacks are least likely to study abroad, while Whites are most likely to participate $[1,21,91,92]$. It is because these groups represent the greatest disparity in study abroad participation that we chose to focus on their experiences in the qualitative component of this study.

7. Table 4 provides a summary of several relevant characteristics for the twenty-one interviewed students. Pseudonyms of students and those they referred to were used to ensure confidentiality. We also changed the names of some of the study abroad locations in order to further protect their identities.

8. According to Lareau and Weininger, university agents generally assume that students have a "universal" understanding of the application process [93]. However, students unfamiliar with the nuances of the process will have problems complying with its requirements.

9. This hesitancy to borrow money among lower class students is likely due to cultural, social, and psychological factors that consider borrowing money as a burden rather than a relief [94]. Students who were more familiar with the loan process - if they funded aspect of their college education with loans-were more willing to fund study abroad through loans than students who had not utilized this method before. Perna [94] found that socioeconomic advantage is positively correlated with borrowing money from lending agencies (page 1630).

\section{References}

[1] R. W. Booker, Differences between applicants and non-applicants relevant to the decision to apply to study abroad [Ph.D. thesis], Department of Higher Education, University of Missouri-Columbia, 2001.

[2] A. V. Carroll, The participation of historically underrepresented students in study abroad programs: an assessment of interest and perception of barriers [M.S. thesis], School of Education, Fort Collins, Colorado State University, 1996.

[3] H. Carter, "Minority access to international education," in Black Students and Overseas Programs: Broadening the Base of Participation, CIEE, Ed., pp. 6-13, CIEE: Council on International Educational Exchange, New York, NY, USA, 1991.

[4] L. A. Hembroff and D. L. Rusz, "Minorities and overseas studies programs: Correlates of differential participation," Occasional Paper No. 30, New York, NY, USA, Council of International Educational Exchange (CIEE), ERIC Document Reproduction Service No ED 368 283, 1993.

[5] P. R. Mattai and O. Godwin, "Some mitigating factors against African-Americans in the rural American South opting to study abroad," Paper presented at the Annual Conference on International Educational Exchange. Washington, DC, USA, ERIC Document Reproduction Service No. ED 315 474, 1989.

[6] J. S. Van Der Meid, "Asian Americans: factors influencing the decision to study abroad," Frontiers: The Interdisciplinary Journal of Study Abroad, vol. 9, Fall 2003, 1999, http://www.frontiersjournal.com.
[7] B. Adelman Mara, "The Impact of an international education on college acceptance and career development," American Institute for Foreign Study. ERIC Document Reproduction Service No. ED 298 056, 1988.

[8] B. David, "Global competence and international student exchange: attitudinal preparation for effective learning," in Educational Exchange and Global Competence, R. D. Lambert, Ed., pp. 189-198, CIEE: Council on International Educational Exchange, New York, NY, USA, 1994.

[9] B. F. Hadis, "Gauging the impact of study abroad: how to overcome the limitations of a single-cell design," Assessment and Evaluation in Higher Education, vol. 30, no. 1, pp. 3-19, 2005.

[10] J. Shaftel, T. Shaftel, and R. Ahluwalia, "International educational experience and intercultural competence," International Journal of Business and Economics, vol. 6, pp. 25-34, 2007.

[11] S. Talburt and M. A. Stewart, "What's the subject of study abroad?: race, gender, and 'living culture," Modern Language Journal, vol. 83, no. 2, pp. 163-175, 1999.

[12] B. Burn, L. Cerych, and A. Smith, Eds., Study Abroad Programmes, Jessica Kingsley, London, UK, 1990.

[13] A. Chadwick, "Potential of International Education in Building a More Participatory World," in Research on Exchanges Proceedings of the German American Conference of Wissenschaftszentrum, M. Stassen, Ed., DAAD, Bonn, German, 1980.

[14] B. David and U. Zeutschel, Utilizing the Effects of Youth Exchange: A Study of the Subsequent Lives of German and American High School Exchange Participants, Council on International Education Exchange, New York, NY, USA, 1994.

[15] J. S. Carlson, B. B. Burn, J. Useem, and Y. David, Study Abroad: The experience of American Undergraduates, Greenwood Press, New York, NY, USA, 1990.

[16] M. Chichester and S. Akomolafe, "Minorities and underrepresented groups in international affairs and the foreign policy establishment," Paper presented at the Global Challenges \& U.S. Higher Education Conference, Duke University, January, http://www.duke.edu/web/cis/globalchallenges/ research_papers.html.

[17] B. High, American Studies and the Year Abroad: A Rebuttal to Mills, [Letter to the Editor], British Association of American Studies no. 78, 1998.

[18] R. D. Lambert, International Studies and the Undergraduate, American Council on Education, Washington, DC, USA, 1989.

[19] D. Washington, African-American undergraduate students' perceptions of and attitudes toward study abroad programs [Ph.D. thesis], Graduate School of Education, George Mason University, 1998.

[20] J. Hoff, J. S. Van Der Meid, and T. Doan, "Asian American participation in study abroad," in Presentation at the Annual CIEE: Council on International Educational Exchange Conference, Atlanta, Ga, USA, 2002.

[21] Institute of International Education, Open doors 2006: Study abroad: U.S. Student Profile, 2006, http://opendoors.iienetwork.org/?p=89220.

[22] D. Comp, "Initiatives in 2006 to Increase Student Diversity in Education Abroad," Paper presented at the Academy for Educational Development's Colloquium on Diversity in Education Abroad, 2006.

[23] J. B. Cole, "Opening address of the 43rd International Conference on Educational Exchange: international education: Broadening the base of participation. CIEE: Council on International Educational Exchange Annual Conference, Charleston, South Carolina," in Black Students and Overseas Programs: Broadening the Base of Participation, CIEE, Ed., pp. 
1-5, CIEE: Council on International Educational Exchange, New York, NY, USA, 1990.

[24] A. Dessoff, "Who's not going abroad?" International Educator, 2006.

[25] L. Chieffo, "Determinants of Student Participation in Study Abroad Programs at the University of Delaware: A Quantitative Study," Ed. D. executive position paper, University of Delaware, 2000.

[26] R. W. Surridge, Factors deterring adult undergraduate students at penn state capital college from participation in study abroad [Ph.D. thesis], The Pennsylvania State University, 2000.

[27] L. R. Miller, Undergraduate participation in study abroad, internship and research programs: cultural capital variables [Ph.D. thesis], Department of Education, University of California.

[28] C. A. Jarvis and K. Jenkins, Educating for the Global Future, Black Issues in Higher Education, 2000.

[29] I. Norton, "Changing the Face of Study Abroad: Colleges Reach Out to Minority Students in Effort to Reduce Racial Disparities," The Chronicle of Higher Education, 2008.

[30] P. Bourdieu, "Cultural reproduction and social reproduction," in Power and Ideology in Education, J. Karabel and A. H. Halsey, Eds., pp. 487-511, Oxford University Press, New York, NY, USA, 1977.

[31] D. Swartz, Culture and Power: The Sociology of Pierre Bourdieu, University of Chicago Press, Chicago, Ill, USA, 1997.

[32] A. Nieoczym, Globalization, tourism and the commodification of imagination: an ethnography of backpacking [M.S. thesis], Simon Fraser University, 2003.

[33] M. H. Salisbury, P. D. Umbach, M. B. Paulsen, and E. T. Pascarella, "Going global: understanding the choice process of the intent to study abroad," Research in Higher Education, vol. 50, no. 2, pp. 119-143, 2009.

[34] G. Ladson-Billings, "Just what is critical race theory and what's it doing in a nice field like education?" International Journal of Qualitative Studies in Education, vol. 11, pp. 7-24, 1998.

[35] P. Willis, Learning to Labor: How Working Class Kids Get Working Class Jobs, Columbia University Press, New York, NY, USA, 1977.

[36] R. D. Stanton-Salazar and S. M. Dornbusch, "Social capital and the reproduction of inequality: information networks among Mexican-origin high school students," Sociology of Education, vol. 68, pp. 116-135, 1995.

[37] A. Lareau, Home Advantage: Social Class and Parental Intervention in Elementary Education, Falmer Press, New York, NY, USA, 2000.

[38] A. Lareau and E. M. Horvat, "Moments of social inclusion and exclusion race, class, and cultural capital in family-school relationships," Sociology of Education, vol. 72, no. 1, pp. 37-53, 1999.

[39] K. Monkman, M. Ronald, and F. D. Théramène, "Social and cultural capital in an urban Latino school community," Urban Education, vol. 40, no. 1, pp. 4-33, 2005.

[40] P. Bourdieu and J.-C. Passeron, Reproduction in Education, Society, and Culture, Sage, Beverly Hills, Calif, USA, 1977.

[41] M. Lamont and A. Lareau, "Cultural capital: allusions, gaps and glissandos in recent theoretical developments," Sociological Theory, vol. 6, pp. 153-168, 1988.

[42] V. J. Roscigno and J. W. Ainsworth-Darnell, "Race, cultural capital, and educational resources: persistent inequalities and achievement returns," Sociology of Education, vol. 72, no. 3, pp. 158-178, 1999.
[43] T. A. Fordham, Cultural Capital and the making of the 'blue blazer kids': an ethnography of a youth exchange program [Ph.D. thesis], Maxwell School of Citizenship and Public Affairs, Syracuse University, Syracuse, NY, USA, 2002.

[44] E. Useem, "Middle Schools and Math Groups: parentsInvolvement in children's placement," Sociology of Education, vol. 65, pp. 263-279, 1992.

[45] P. Carter, Keepin it Real: School Success Beyond Black and White, Oxford University Press, New York, NY, USA, 2005.

[46] A. Lewis, Race in the Schoolyard: Negotiating the Color Line in Classrooms and Communities, Rutgers University Press, New Brunswick, NJ, USA, 2003.

[47] P. M. McDonough, Choosing Colleges: How Social Class and Schools Structure Opportunity, State University of New York Press, Albany, NY, USA, 1997.

[48] J. W. Creswell, Research Design: Qualitative and Quantitative Approaches, Sage, Thousand Oaks, Calif, USA, 1994.

[49] J. Coleman, Foundations of Social Theory, Harvard University Press, Cambridge, UK, 1990.

[50] J. W. Ainsworth-Darnell and D. B. Downey, "Assessing the oppositional culture explanation for racial/ethnic differences in school performance," American Sociological Review, vol. 63, no. 4, pp. 536-553, 1998.

[51] B. A. Broh, "Linking extracurricular programming to academic achievement: who benefits and why?" Sociology of Education, vol. 75, no. 1, pp. 69-95, 2002.

[52] D. B. Downey, P. T. von Hippel, and B. A. Broh, "Are schools the great equalizer? Cognitive inequality during the summer months and the school year," American Sociological Review, vol. 69, no. 5, pp. 613-635, 2004.

[53] R. Rothstein, Class and Schools: Using Social, Economic, and Educational Reform to Close the Black-White Achievement Gap, Teachers College Press, 2004.

[54] J. D. Teachman, "Family background, educational resources, and educational attainment," American Sociological Review, vol. 52, pp. 548-557, 1987.

[55] I. Seidman, Interviewing as Qualitative Research: A Guide for Researchers in Education and the Social Sciences, Teachers College Press, New York, NY, USA, 1998.

[56] B. G. Glaser and A. L. Strauss, The Discovery of Grounded Theory: Strategies for Qualitative Research, Aldine, 1967.

[57] R. LaRossa, "Grounded theory methods and qualitative family research," Journal of Marriage and Family, vol. 67, no. 4, pp. 837-857, 2005.

[58] B. Glaser, Theoretical Sensitivity. Advances in the Method of Grounded Theory, Sociology Press, Mill Valley, Calif, USA, 1978.

[59] E. M. Horvat, "The interactive effects of race and class in educational research: theoretical insights from the work of pierre bourdieu," Penn GSE Perspectives on Urban Education, vol. 2, pp. 1-25, 2003.

[60] E. M. Horvat and A. L. Antonio, "Hey, those shoes are out of uniform': African American girls in an elite high school and the importance of habitus," Anthropology and Education Quarterly, vol. 30, no. 3, pp. 317-342, 1999.

[61] G. H. Stoop, "Minority student participation in study abroad," Journal of the Association of International Education, vol. 8, no. 1, pp. 1-6, 1988.

[62] M. McPherson, L. Smith-Lovin, and J. M. Cook, "Birds of a feather: homophily in social networks," Annual Review of Sociology, vol. 27, pp. 415-444, 2001.

[63] B. D. Tatum, Why are all the Black Kids Sitting Together in the Cafeteria? and Other Conversations About Race, vol. 1997, Basic Books, New York, NY, USA. 
[64] J. Landau and D. C. Moore, "Towards reconciliation in the motherland: race, class, nationality, gender, and the complexities of American Student Presence at the University of Ghana, Legon," Frontiers: The Interdisciplinary Journal of Study Abroad, vol. 7, pp. 25-60, 2001.

[65] P. McIntosh, "White privilege and male privilege: a personal account of coming to see correspondences through work in women's studies," in Race, Class, and Gender, M. L. Andersen and P. H. Collins, Eds., Wadsworth, Boston, Mass, USA, 1998.

[66] N. Day-Vines and J. Barker, "Impact of diasporic travel on the racial identity development of African American college students," The College Student Journal, vol. 32, pp. 463-471, 1998.

[67] R. M. Morgan, T.D. Mwegelo, and N. L. Turner, "Black women in the African diaspora seeking their cultural heritage through studying abroad," NASPA Journal, vol. 39, pp. 333-353, 2002.

[68] X. D. S. Briggs, Bridging networks, social capital, and racial segregation in America (Faculty Research Working Paper Series, \#RWP02-011), Boston, Mass, USA, Harvard University, John F. Kennedy School of Government, 2003.

[69] M. Granovetter, “The strength of weak ties," American Journal of Sociology, vol. 78, pp. 1360-1380, 1973.

[70] R. D. Putnam, Bowling Alone: The Collapse and Revival of American Community, Simon and Schuster, New York, NY, USA, 2000.

[71] R. D. Stanton-Salazar, "A social capital framework for understanding the socialization of racial minority children and youths," Harvard Educational Review, vol. 67, no. 1, pp. 1-40, 1997.

[72] M. Fine, L. Weis, C. L. Powell, and L. M. Wong, Off White: Readings on Race, Power, and Society, Routledge, NewYork, NY, USA, 1997.

[73] B. B. Rasmussen, E. Klinenberg, I. J. Nexica, and M. Wray, The Making and Unmaking of Whiteness, Duke University Press, Durham, NC, USA, 2001.

[74] W. R. Allen, "Black colleges vs. White colleges: the fork in the road for Black students," Change, vol. 19, no. 3, pp. 28-31, 1987.

[75] A. D'Augelli and S. Hershberger, "African American undergraduates on a predominantly white campus: academic factors, social networks, and campus climate," Journal of Negro Education, vol. 62, pp. 67-81, 1993.

[76] R. Smith-Maddox, "The social networks and resources of African American eighth graders: evidence from the national education longitudinal study of 1988," Adolescence, vol. 34, no. 133, pp. 169-183, 1999.

[77] J. Hochschild, Facing Up To the American Dream: Race, Class, and the Soul of the Nation, Princeton University Press, Princeton, NJ, USA, 1995.

[78] J. Lee, "The salience of race in everyday life: black customers' shopping experiences in black and white neighborhoods," Work and Occupations, vol. 27, no. 3, pp. 353-376, 2000.

[79] J. R. Feagin, H. Vera, and I. Nikitah, The Agony of Education: Black Students at White Colleges and Universities, Routledge, New York, NY, USA, 1996.

[80] J. Fleming, Blacks in College: A Comparative Study of Students' Success in Black and White Institutions, Jossey-Bass, San Francisco, Calif, USA, 1984.

[81] M. Nettles, A. R. Thoeny, and E. Gossman, "Comparative and predictive analysis of black and white Students', college achievement and experience," Journal of Higher Education, vol. 57, pp. 289-318, 1986.

[82] S. S. Willie, Acting Black: College, Identity, and the Performance of Race, Routledge/Falmer, New York, NY, USA, 2003.
[83] B. J. C. Gossett, J. Michael, and I. Cockriel, "African Americans' perception of marginality in the college culture," College Student Journal, vol. 32, no. 1, pp. 22-32, 1998.

[84] L. Delpit, Other People's Children: Cultural Conflict in the Classroom, New Press, New York, NY, USA, 1995.

[85] J. M. Stuber, "Class, culture, and participation in the collegiate extra-curriculum," Sociological Forum, vol. 24, no. 4, pp. 877900, 2009.

[86] L. Engle and J. Engle, "Abroad levels: towards a classification of program types, frontiers: the interdisciplinary," Journal of Study Abroad, vol. 9, pp. 1-20, 2003.

[87] Report of the University of Kansas Task Force on Internationalization, 2001, http://www2.ku.edu/ oip/pdf/International_ Task_Force_Report.pdf.

[88] University System of Georgia and Board of Regents, Office of International Education, UGA Study Abroad Participation FY1998-FY, 2008, http://www.usg.edu/international_ed/facstaff/policies/index.phtml\#statistics.

[89] University System of Georgia and Board of Regents, Office of Strategic Research and Analysis, Semester Enrollment Report Fall, 2006, http://www.usg.edu/research/students/enroll/ fy2006/.

[90] “Office of International Affairs," 2007.

[91] J. S. Johnston Jr. and R. J. Edelstein, "Beyond borders: profiles in international education," Tech. Rep. 29674044, American Assembly of Collegiate Schools of Business, and Association of American Colleges, Washington, DC, USA, 1993.

[92] "Advisory Council for International Educational Exchange Report," Tech. Rep., Council on International Educational Exchange, New York, NY, USA, 1988.

[93] A. Lareau and E. B. Weininger, "Cultural capital in educational research: a critical assessment," Theory and Society, vol. 32, no. 5-6, pp. 567-606, 2003.

[94] L. W. Perna, "Understanding the relationship between information about college prices and financial aid and students' college-related behaviors," American Behavioral Scientist, vol. 49, no. 12, pp. 1620-1635, 2006. 

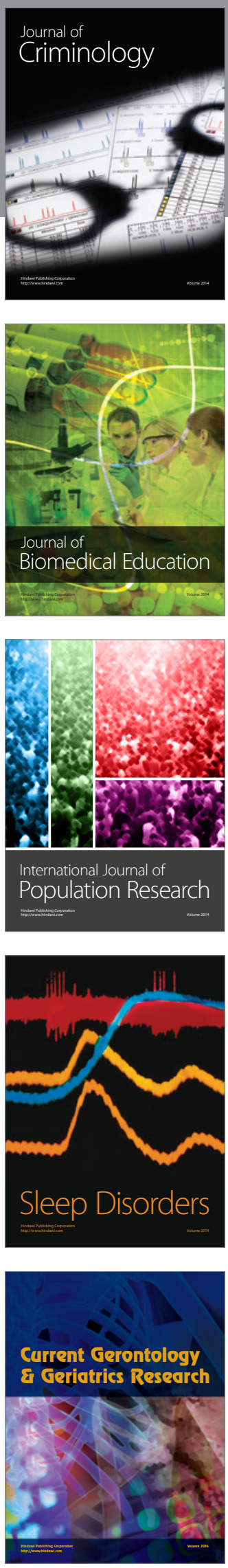
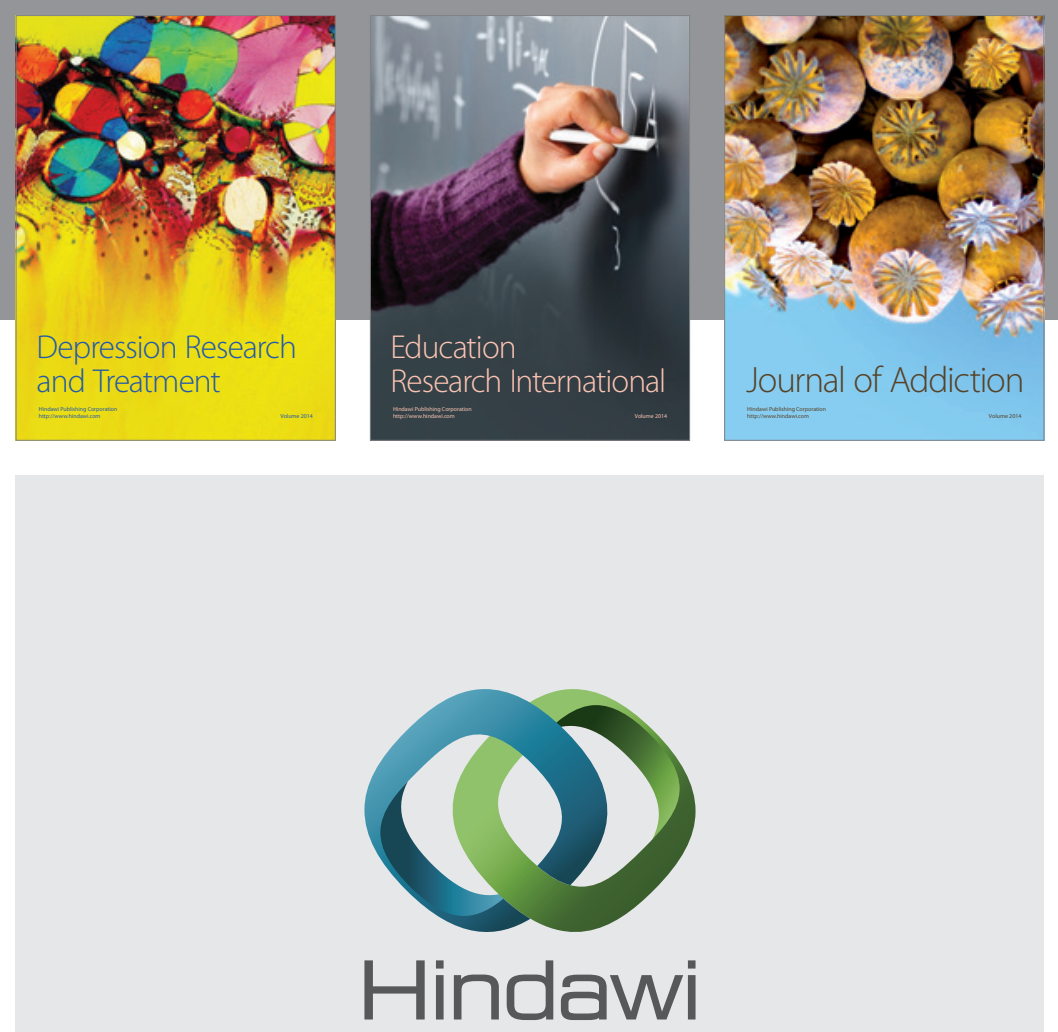

Submit your manuscripts at

http://www.hindawi.com

Child Development Research
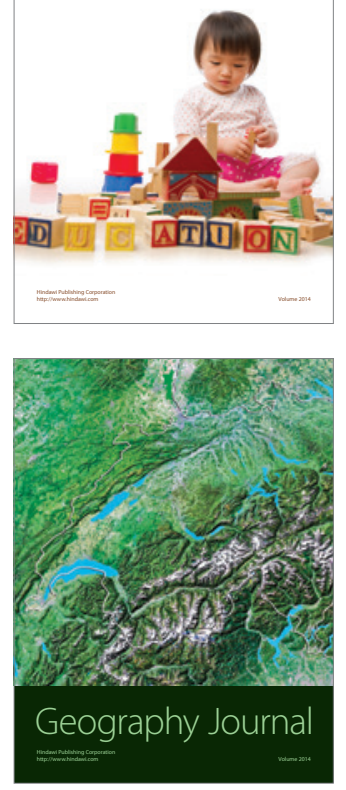

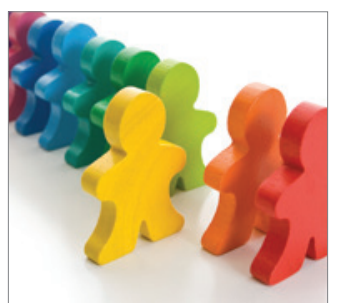

Autism

Research and Treatment
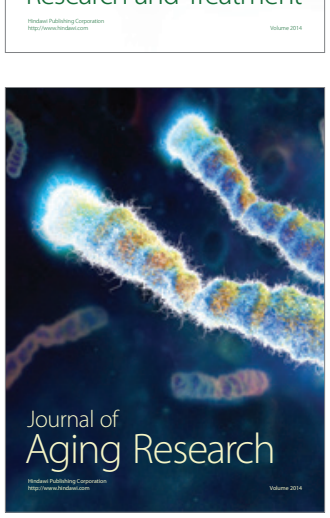
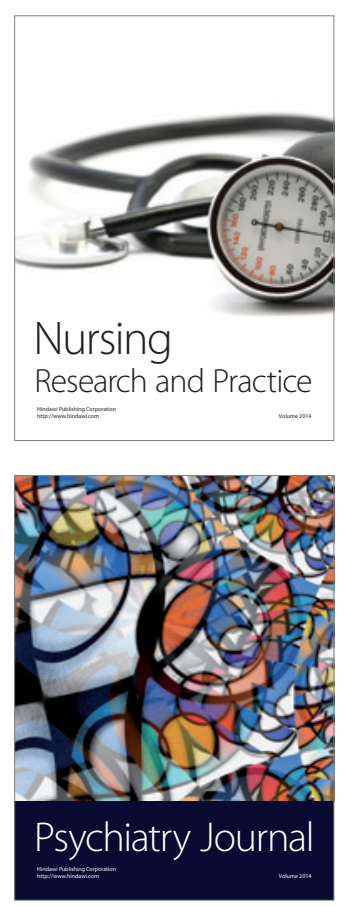
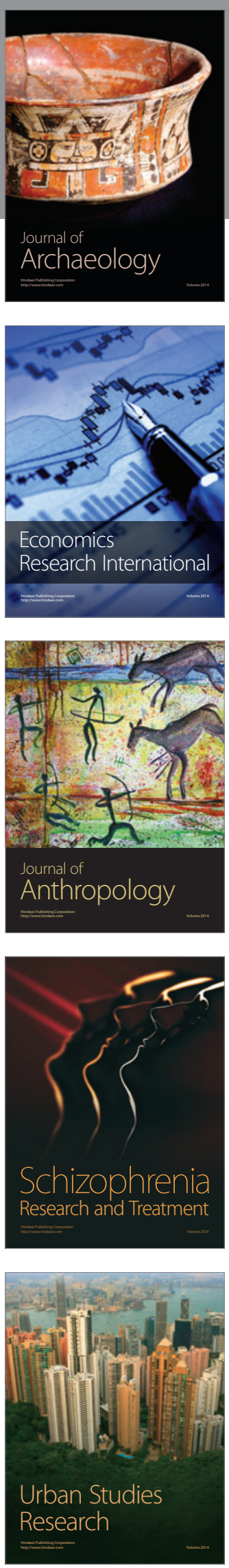